\title{
Author Correction: Multiple sclerosis
}

Massimo Filippi, Amit Bar-Or, Fredrik Piehl, Paolo Preziosa, Alessandra Solari, Sandra Vukusic and Maria A. Rocca

Nature Reviews Disease Primers 4, Article number: 43 (2018) https://doi.org/10.1038/

s41572-018-0041-4 Published online 08 November 2018

In the originally published version of this article, in Table 4, Ocrelizumab was incorrectly referred to as an anti-CD25 antibody. This has been corrected in the HTML and PDF versions of the article to an anti-CD20 antibody.

https://doi.org/10.1038/s41572-018-0050-3 I Published online: 22 November 2018 